\title{
Higher Education as a Determinant of the Competitiveness of the National Economy
}

\author{
Miloš Krstić1, Nebojša Pavlović \\ ${ }^{1}$ Faculty of Sciences and Mathematics, University of Niš, Serbia \\ ${ }^{2}$ Faculty of Hotel Management and Tourism, University of Kragujevac, Serbia
}

\begin{abstract}
The aim of this paper is to contribute to a clearer understanding of the impact of higher education on the competitiveness of the national economy. The realization of this research was carried out by applying correlation and regression analysis. The results of research show that there is a direct correlation between higher education and the level of national competitiveness. The key contribution of this paper is that, based on previous literature and published results of scientific research, it gives a clearer insight into the competitiveness factors of the analyzed countries expressed in the field of higher education, and indicates the priority activities of the competent state bodies for advancement and raising the level of competitiveness of the national economy.
\end{abstract}

Keywords: Higher Education, Reforms, Skills, The New Methodology of the Global Competitiveness Index, the employability of students, Dual Education System in Higher Education Institutions

\section{Introduction}

The significance of the nine-century long history of higher education for the development of today's Europe is definitely big and indisputable, as it is its reputation and influence around the world. The first and oldest university in the world is the University of Bologna, Italy, was founded in 1088. It should therefore be no surprise that Europe has always paid great attention to the development of higher education on its own territory. There are numerous reasons for this. First, the potential of higher education to stimulate economic development, social cohesion and improve the quality of life in society is high. Every 
additional year of education above the population average is estimated as increasing the country's average productivity by $6.2 \%$ (de la Fuente and Jimeno, 2005). Second, the higher education system enables higher employment rates to be achieved (Lavrinovicha et al., 2015). According to the scientific research of Federico Biagi and Claudio Lucifora conducted in 10 countries of the European Union, it can be concluded that higher education level reduces unemployment (Biagi and Lucifora, 2008). Third, the impact of higher education on society is significant even in reducing crime rates and in the higher active participation of educated people in social life. Population with lower level of education is considered to be physically inactive and more susceptible to obesity than more educated population. This also can be applied to the mental health of individuals. Individuals with lower incomes or less material resources are poorly educated and often suffer from depression, especially in northern Europe. According to Eurostat survey from 2010th, a systematic relationship was found between education levels and mortality. Life expectancy is lower for less educated social groups and increases with education level (EC-DG ECFIN, 2010, p. 16).

Undoubtedly, higher level of education provides clearer picture of the world and how the world works. New knowledge changes people, their habits and values. After all, they are changing individuals, society and the world for the better. Therefore, any humane, social and responsible society that seeks to ensure continued GDP growth and world-class quality of life should always have (higher) education in the focus of interest.

Although Europe has always been known as the world's university center and incubator of global intelligence, in recent decades, European higher education institutions seem to be failing to "keep up" with the best universities in Anglo-Saxon countries that seem to dominate the market. Many world rankings (universities), such as the list of Shanghai Universities (Chinese University Rankings) or Times Higher Education (British University Rankings), show that the top 20 universities come from Anglo-Saxon countries. For example, in the academic year 2019/2020 on the Shanghai List, only four European universities are among the top 20 universities in the world: the Swiss Federal Institute of Technology Zurich (Switzerland), the University of Cambridge, the University of Oxford and University College London (United Kingdom) (Cheng, 2015).

The text is structured in following manner. The first part presents the reforms in higher education in Europe. Then, in the second part, the characteristics of the higher education system in Serbia are analyzed. The third part outlines the methodology and information base of the research and defines the starting hypotheses. The fourth part of the paper deals with the research results and discuss it. The concluding considerations provide recommendations for undertaking desirable activities by the competent state authorities in order to improve higher education and raise the level of national competitiveness.

\section{Reforms in European Higher Education}

In the late 1990s, awareness of global competition increased in European higher education. It is understood that despite the success achieved in advancing (improving) 
intra-European mobility, the "picture" of the visibility of European higher education institutions outside Europe is still not sufficiently successful. Europe has lost its position as an ideal destination for international students in the US. Also, Europe had significantly less effective degree structures (or degrees) than the US graduates entered the job market at an older age than American. Awareness of these factors has led to initiatives at various levels. First, the ministers of Great Britain, Germany, France and Italy called for the equalization of diplomas. This was the initiative that launched the Bologna Process. In 1999, the Ministers of Education of 29 European countries signed the so-called Bologna Declaration in Bologna (European Commission, 2001).

The European Commission (EC) itself became more active in the field of education only after the meeting of the Prime Ministers and EU Member States, held in March 2000th in Lisbon. At the meeting, representatives of EU member states stated that by the 2010th the European Union should become the most competitive and dynamic knowledge-based economy in the world. Higher education has been identified as one of the key areas in achieving this goal, which has provided the EC with political mandate in the higher education policy segment. The EC has also been able to develop wide range of initiatives, and on its basis has been created the Lisbon Strategy (European Commission, 2002; Lisbon Council, 2007).

In the EC document on university reform entitled Delivering on the modernization agenda for universities: education, research and innovation, is pointed out the following: "With 4,000 institutions, over 17 million students and about 1.5 million employees -435.000 of whom are researchers - higher education institutions in Europe have great potential, but that potential has not been fully utilized and put into function of economic growth and development. ... Continued globalization means that the European Higher Education Area and the European Research Area must be open to the world and become competitive players at the global level ... Universities are key players for European future and successful transition to knowledge-based economy and society. ... Yet, this key sector of society needs deep restructuring and modernization if Europe is to win the global competition in the education market" (European Commission in UK, 2006).

In the following, certain characteristics of the higher education system in Serbia are analyzed. In addition to the emphasis on the underfunding of higher education institutions in Serbia, they also pointed on the negative effects of the implementation of the Bologna Declaration on the quality of higher education.

\section{The State of Higher Education in the Republic of Serbia}

Today, higher education in the Republic of Serbia is treated as a public good. Universities have undergone serious expansion. The number of students increased from 145,493 students in 2007 to 195,256 students in 2019. The increase in student numbers was accompanied by an even larger increase in the number of universities - from several state universities in 2000/2001. up to 18 universities in 2019 (8 state and 10 private) (Krstić 
and Krstić, 2015). Unfortunately, budgetary allocations for education did not meet the growing needs of higher education. All this has led to Serbia's low rating.

A serious problem is the implementation of the Bologna Declaration, which according to many authors (Topić, 2014; Cavalli et al., 2019; Krstić and Krstić, 2017), has negative effects on the quality of higher education which is why deep reforms of the entire education system are also needed. From the Humboldt system of study, when the studies were more thorough, it went to the extreme of the absurdly easy acquisition of higher education diplomas. We have unburdened the curricula of the "subject-matter knowledge". We have kept the exam preparation literature to a minimum. We have done all this by striving for higher education that will be effective, productive and competitive. Being guided by economic categories, it is as if we have forgotten that education has its lasting humanistic values, such as knowledge as value, justice, freedom, equality of citizens, etc (Pavlović, 2017).

The next part of the paper defines the research objective, hypotheses and explanations of higher education research methodologies in selected countries. The research was conducted according to the concept of the Global Competitiveness Index 4.0 of the World Economic Forum.

\section{Methodological Framework for Research and Hypotheses}

We conducted this research to examine the impact of tertiary education on the competitiveness of the national economy (research objective). We believe that the World Economic Forum's "Skills" index determines (predicts) the results of the Global Competitiveness Index 4.0. In our research, we collected data on the "Skills" Index for a group of 36 countries. However, Professor Marija Ivaniš, our colleague, believes that we should not use the "Skills" Index as a predictor variable, but should use individual indicators of the World Economic Forum and Eurostat related to higher education.

Professor Marija Ivaniš states that some indicators of the World Economic Forum and Eurostat better predict the results of the Global Competitiveness Index 4.0 compared to the "Skills" index. Based on the advice we received from Maria, we decided to conduct multiple regression analyzes with seven predictor variables: 1) "Skillset of graduates" $(S o G), 2)$ "Critical thinking in teaching" (CTiT), 3) "Scientific Publications "(SP), 4) "Patent applications" $(P A), 5)$ "Research institutions prominence" $(R I P), 6)$ "R\&D expenditures" $(R D E)$, and 7) "Total public expenditure at tertiary level of education" (TPET).

As we began to see that the World Economic Forum and Eurostat indicators were more effective in predicting the Global Competitiveness Index 4.0 (criterion variable) than the "Skills" index, we decided to divide the predictor variables (or indicators) into three groups: measures for "quality of teaching in the higher education system ", measures for the "quality of science and research at university" and indicators of funding for the higher education system. Measures for "quality of teaching in the higher education system" are: "Skillset of graduates" and "Critical thinking in teaching" (indicators of the World 
Economic Forum). Measures for "quality of science and research at university" are: "Scientific publications", "Patent applications" and "Research institutions prominence" (indicators of the World Economic Forum). Financing indicators for higher education include: "Total public expenditure at tertiary level of education" and "R\&D expenditures" (Eurostat indicators).

However, Marija Ivaniš reminded us that at the beginning of our research we also collected data on the financial system in the countries. She thinks countries that have had financial problems may be less competitive. If this assumption (about the country's "financial health") is true, then the low scores for the variables "Skillset of graduates", "Critical thinking in teaching, "R\&D" expenditure, etc. are not what leads to low competitiveness. To explore this possibility, Maria suggested that we first analyze whether, for example, Eurostat variables relating to the country's financial situation - GDP per capita in PPS (index - EU28 = 100) and Export of goods and services in \% of GDP, have significant impact on Global Competitiveness Index 4.0. If so, then we should evaluate the extent to which variables "Critical thinking in teaching", "Scientific publications", "Skillset of graduates", etc. help predict the Global Competitiveness Index 4.0, through indicators of the country's "financial health".

As previously stated, the information basis for the research is the data contained in the Global Competition Report 2019 of World Economic Forum (WEF).

It is the fact that numerous international institutions create indices on the basis of which they mesure and rank countries according to various aspects of competitiveness, but the most influential are the global indices of the World Economic Forum and the International Institute for Management Development. The paper uses the composite index of the World Economic Forum, first of all, because the report of this international institution covers far larger number of countries than the report of the International Institute for Management Development (Lovrinčević et al., 2008; Krstić et al., 2018).

Based on the results of complex analysis of WEF experts, new tool for assessing the performance of world economies, named the Global Competitiveness Index 4.0, expresses the ability of country to compete with other countries in the conditions of the fourth industrial revolution. According to the Global Competitiveness Index 4.0, the country's competitiveness is assessed on the basis of 12 pillars of competitiveness, which are the most important determinants of the long-term growth of national economies and their profits. Changes in the results (or performance) of GCI 4.0 explain over $80 \%$ of variations in income levels and 70\% of variations in long-term growth of countries and economies (Schwab, 2019).

With all of the above in mind, the aim of this paper is to analyze the impact of higher education systems on the competitiveness of the national economy and to determine how higher education can contribute to improving national competitiveness. In accordance with the set goal, the following hypotheses were defined and tested:

H1: Variable "Scientific publications" compared to the measures "Skillset of graduates", "Critical thinking in teaching", "Patent applications", "Research institutions prominence", 
"Total public expenditure on tertiary level of education" and "R\&D expenditures" better determines the Global Competitiveness Index 4.0.

H2: Variables for "quality of teaching in higher education system" have statistically significant effect on the competitiveness of the economy.

H3: Variables for "science and research at university" predict statistically significant global competitiveness index of 4.0 via the variables "quality of teaching in higher education".

H4: Variables for "science and research at university" have a statistically significant effect on the competitiveness of the national economy.

H5: Variables for "quality of teaching in higher education" predict statistically significant global competitiveness index 4.0 over variables for "science and research at university".

H6: The country's previous financial difficulties lead to low competitiveness of the national economy.

H7: Countries that have high scores in one area of "strength" rating or quality of higher education systems generally have high scores in other areas of quality assessment of the higher education system and vice versa.

H8: The quality of the higher education system in selected areas (the quality of teaching in the higher education system and the quality of science and research at university) is crucially dependent on the amount of public expenditure on higher education.

In order to achieve the goal of research and to confirm or refute hypotheses, in the paper we will apply: multiple regression analysis and correlation analysis. Multiple regression analysis aims to show the impact of measures for higher education quality at the achieved level of the Global Competitiveness Index 4.0. Correlation analysis will be used to determine does interdependence between the variables: "Skillset of graduates", "Critical thinking in teaching", "Scientific Publications", "Total public expenditure on tertiary level of education", "Research institutions prominence" exist? The study was performed on two samples. Sample I includes $E U$ countries, candidate countries ${ }^{1}$ and countries have signed the Stabilization and Association Agreement ${ }^{2}$. Sample II covers countries from sample I that have low ${ }^{3}$ GDP per capita in PPS (index - EU 28=100) and/or low Export of goods and services in \% of GDP.

The next part of the paper is devoted to the analysis and discussion of the results of multiple regression with one set of predictor variables, with two unordered sets of predictor variables, and with 2 ordered sets of predictor variables.

\footnotetext{
${ }^{1}$ Northern Macedonia, Serbia, Montenegro, Albania and Turkey.

${ }^{2}$ Bosnia and Herzegovina.

${ }^{3}$ The result of a variable or indicator is low (or high) as long as it is below (or above) the mean of the result of that variable.
} 


\section{Research Results and Discussion}

\section{Multiple regression with one set of predictor variables}

The results of multiple regression analysis with one set of predictor variables are shown in Figure 1. in the Model Summary table. The regression equation or prediction equation with seven (predictor) variables is statistically significantly related to the Global Competitiveness Index 4.0., $\mathrm{R}^{2}=0.898$, adjusted $\mathrm{R}^{2}=0.868, \mathrm{~F}(7,24)=30.137$; $\mathrm{p}=0.000<0.005$ (we have proved hypothesis 1 ). The regression formula includes partial slopes or B values that are marked in the Unstandardized Coefficients column (George and Mallery, 2016; Savić et al., 2019). According to these B values, the regression equation is:

Predicted Global Competitiveness Index $4.0=2.543$ Skilset of Graduates +2.371 Critical thinking in teaching $+0.000 R \& D$ expenditure +1.127 Total public expenditure at tertiary level of education +0.009 Scientific publications +0.010 Patent applications per million pop. +1.789 Research institutions prominence

The maximum partial slope in the Standardized Coefficients column (see Beta in the Coefficients table) is 0.393 , which is the value for the "Scientific publications". This means that this predictor variable most contributes to explaining the Global Competitiveness Index 4.0 (Hinton et al., 2014). The variable "Scientific publications" makes a unique and statistically significant contribution to explaining the changes in the Global Competitiveness Index 4.0 (the value in the Sig column for this variable is 0.005 ). Other variables in the model (or equation) are not statistically significant in explaining changes in the Global Competitiveness Index 4.0 in the analyzed countries.

From a standpoint of the topic of the paper, it should be emphasized that the results of multiple linear regression analyzes indicate that improving "Scientific publications" should be the primary goal of public policy makers in countries with few papers in international citation databases (Web of Science, Scopus etc.). A country that has few papers in bases such as Web of Science, Scopus and the like should only fund the best researchers in order to achieve excellence in research and improve the competitiveness of the national economy. However, this model of science funding will only be effective if other measures are introduced in parallel, such as: providing modern equipment, improving working conditions and establishing adequate criteria for evaluating results (Krstić et al., 2019; Krstić, 2018).

\section{Multiple regression with two unordered sets of predictor variables}

In the study, we also want to determine if and how well the Global Competitiveness Index 4.0 is predicted by each set of predictor variables?, which in this case are measures for "quality of teaching in the higher education system" and measures for the quality of "science and research at university". In addition, we are interested how well each set of predictor variables predicts the Global Competitiveness Index 4.0 over another set of predictor variables? The results of the first analysis are shown in Figure 2. The first 
analysis estimates how well the Global Competitiveness Index 4.0 is predicted by the measures for "quality of teaching in the higher education system" and how well the Global Competitiveness Index 4.0 is predicted by the measures for "science and research at university" over measures for "quality of teaching in the higher education system". The relation between the measures for "quality of teaching in higher education" and the Global Competitiveness Index 4.0 is statistically significant, $\mathrm{R}^{2}=0.696$; adjusted $\mathrm{R}^{2}=0.677, \mathrm{~F}$ $(2,33)=37,743 ; p=0.000<0.05$ (we have proved hypothesis 2 ). Also, measures for "science and research at university" predict a statistically significant the Global Competitiveness Index 4.0 through measures for "quality of teaching in the higher education system", $\mathrm{R}^{2}$ change $=0.179 ; \mathrm{F}(3,30)=14,236 ; \mathrm{p}=0.000<0.05$ (see Change Statistic column, second row) (we have proved hypothesis 3 ).

The results of multiple regression with two unordered sets of predictor variables allow us to draw the following conclusion. Governments in the analyzed countries should be involved in the implementation of all activities aimed at improving the quality of work of higher education institutions and the quality of learning outcomes. As some of the most important among these activities, we have recognized the following: 1) introduction of a quality dual system in the higher education system and support for the development of all forms of cooperation between higher education institutions and the economy; 2) encouraging the mobility of students and teaching staff; 3) encouraging the formation of joint study programs of domestic and foreign universities and the like (Mbonigaba and Wilfred, 2019; Highman, 2019).

The results of the second analysis are shown in Figure 3. The second analysis estimates how well does the Global Competitiveness Index 4.0 is predicted by the "science and research at university" measures and how well the Global Competitiveness Index 4.0 is predicted by the "quality of teaching in higher education" measures across measures for "science and research at university". We find that measures for "science and research at university" predict a statistically significant the Global Competitiveness Index 4.0, $\mathrm{R}^{2}=$ 0.785; adjusted $\mathrm{R}^{2}=0.765, \mathrm{~F}(3,32)=38$. 949; $\mathrm{p}=0.000<0.05$ (Fig. 2) (we have proved hypothesis 4). Also, measures for "quality of teaching in higher education" predict a statistically significant global competitiveness index of 4.0 through "science and research at university" measures, $R^{2}$ change $=0.089 ; F(2,30)=10.693 ; p=0.000<0.05$ (Fig. 3 ) (we have proved hypothesis 5 ).

\section{Multiple regression with two ordered sets}

Finally, we want to determine whether and how well the Global Competitiveness Index 4.0 is predicted by the country's financial difficulties, as well as whether and how well measures for "quality of teaching in the higher education system", measures for "science and research at university and indicators for financing higher education ("Total public expenditure on tertiary level of education" and "R\&D expenditure") predict Global Competitiveness Index 4.0 after controlling for the impact of a country's financial problems (first set of predictor variables)? 
The results of multiple regression with two ordered sets of predictor variables are shown in Figure 4. The first set of predictor variables - GDP per capita in PPS (index - EU = 100) and the Export of goods and services in \% of GDP have a positive effect at the Global Competitiveness Index 4.0, $\mathrm{R}^{2}=0.859$; adjusted $\mathrm{R}^{2}=0.824, \mathrm{~F}(2,8)=24.441 ; \mathrm{p}=0.00<0.05$ (Figure 4) (we have proved hypothesis 6).

The result of research indicates that some countries, that are the subject of this study (see Table 1) should pay more attention to the current account deficit and balance of payments developments. As is well known, the current account deficit shows how much states, businesses and citizens spend more than they create. As the state imports much more than it exports and as foreign investors, on various ways, continually export money, current outflows of foreign exchangeare much higher than inflows.

Tab. 1: Selected countries with current account deficits in sample II

\begin{tabular}{|l|c|c|c|}
\hline \multicolumn{1}{|c|}{ Countries } & Export & Import & Current account deficit \\
\hline Romania & 85102.9 & 91242.9 & 61400 \\
\hline Northern Macedonia & 6480.7 & 7825.9 & 13452 \\
\hline Albania & 4050.1 & 5802.9 & 17528 \\
\hline Serbia & 21760.1 & 25410.3 & 36502 \\
\hline Bosnia and Herzegovina & 6932.8 & 9528.1 & 25953 \\
\hline
\end{tabular}

Source: Author's calculation based on Eurostat data in 2018th year

(Available from: https://ec.europa.eu/eurostat).

The macro balance that best reflects the financial risks of a country is an international investment position or balance sheet. What is a negative value of balance sheet more, that the risk of financial crisisis greater. A key factor contributing to the increase in the negative value of balance sheet is the current account deficit, and this dangerous situation can only be corrected by reducing it. This requires serious correction of exchange rate and accelerated depreciation. If this does not happen, the increasing current account deficit will have a negative impact on the amount of funds from the budget allocated to tertiary education.

Seven indicators of the strength or quality of the higher education system (variables for "quality of teaching in the higher education system", for "quality of science and research at university" and indicators of financing the higher education system) have a significant proportion of variance of the global competitiveness index 4.0 after controlling for the impact of financial difficulty of country, $\mathrm{R}^{2}$ change $=0.141 ; \mathrm{F}(7,1)=266.746 ; \mathrm{p}=$ $0.047<0.050$ (Fig. 4) .

The results of the partial and two-dimensional correlation analysis, that examining the interdependence of the variables: "Skills of graduate", "Critical thinking in teaching", "Scientific publications", "Total public expenditure on tertiary level of education" and "Research institutions prominence" will be discussed below. 


\section{Two-dimensional and partial correlation}

We hypothesized that countries that have high scores in some area of quality of higher education system are also more likely to have high scores in other areas of quality of higher education system (see hypothesis 7 in the section titled Methodological framework for research and hypotheses). To test this hypothesis, we collected results for 5 variables from the regression equation in a previous study (research of multiple regression). These are the following variables: "Skillset of graduates", "Critical thinking in teaching", "Scientific publications", "Research institutions prominence" and "Total public expenditure on tertiary level of education". In this study, we are particularly interested in the partial correlation between the four measures for quality of the higher education system, excluding the impact of the measure "Total public expenditure on tertiary level of education". The variables in the two-dimensional and partial correlation studies are given in Table 2.

Tab. 2: Analyzed variables

\begin{tabular}{|c|c|c|}
\hline Variable & $\begin{array}{l}\text { Definition of } \\
\text { Variable }\end{array}$ & $\begin{array}{c}\text { Explanation of result } \\
\text { of variable }\end{array}$ \\
\hline Skillset of gradutes & $\begin{array}{l}\text { Measuring the "strength" of } \\
\text { a high education system } \\
\text { related to quality of } \\
\text { teaching in the higher } \\
\text { education system }\end{array}$ & $\begin{array}{l}\text { High scores for this variable } \\
\text { indicate that the higher } \\
\text { education system in a } \\
\text { country creates staff that } \\
\text { meets the demands of the } \\
\text { market and the economy } \\
\text { and who have transferable } \\
\text { skills in accordance with } \\
\text { different contexts }\end{array}$ \\
\hline $\begin{array}{l}\text { Critical thinking } \\
\text { in theaching }\end{array}$ & $\begin{array}{l}\text { Measuring the "strength" of } \\
\text { a high education system } \\
\text { related to quality of } \\
\text { teaching in higher } \\
\text { education }\end{array}$ & $\begin{array}{l}\text { The high results for this } \\
\text { variable indicate that } \\
\text { lectures and exercises } \\
\text { emphasize on illustrations, } \\
\text { tasks and other forms of } \\
\text { knowledge application that } \\
\text { encourage the student to } \\
\text { think, be creative, work } \\
\text { autonomous, etc. }\end{array}$ \\
\hline $\begin{array}{l}\text { Total public expenditure } \\
\text { on tertiary level of } \\
\text { education }\end{array}$ & $\begin{array}{c}\text { Percentage of gross } \\
\text { domestic product (GDP) }\end{array}$ & $\begin{array}{l}\text { High scores for this variable } \\
\text { indicate that the country } \\
\text { allocating large funds for } \\
\text { higher education needs }\end{array}$ \\
\hline Scientific publications & $\begin{array}{l}\text { Measuring the "strength" of } \\
\text { a high education system } \\
\text { that related to the quality of } \\
\text { science and research at } \\
\text { university }\end{array}$ & $\begin{array}{l}\text { High scores for this variable } \\
\text { mean that the country has } \\
\text { effective or productive } \\
\text { researchers in state-owned } \\
\text { scientific organizations } \\
\text { (colleges and institutes) }\end{array}$ \\
\hline $\begin{array}{c}\text { The reputation of scientific } \\
\text { organizations (faculties } \\
\text { and institutes) }\end{array}$ & $\begin{array}{l}\text { Measuring the "strength" of } \\
\text { a high education system } \\
\text { related to the quality of } \\
\text { science and research at } \\
\text { university }\end{array}$ & $\begin{array}{l}\text { Low scores for this variable } \\
\text { means that R\&D } \\
\text { organizations in a particular } \\
\text { countries have poor results } \\
\text { and do not competitive } \\
\text { enough to function in } \\
\text { market conditions }\end{array}$ \\
\hline
\end{tabular}

Source: Schwab (2019); Leech et al. (2014). 
The results of the two-dimensional and partial correlations are shown in Table 3. Each cell in the table shows a certain correlation coefficient (two-dimensional correlations or partial correlations), a p value of a certain correlation (marked Significance), and a degree of freedom $(\mathrm{df}=\mathrm{N}-2)$.

Tab. 3: Correlations

\begin{tabular}{|c|c|c|c|c|c|c|c|}
\hline \multicolumn{3}{|c|}{ Control Variables } & SOG & CTiT & SP & RIP & TPET \\
\hline \multirow[t]{15}{*}{-none-a } & SOG & Correlation & 1.000 & .844 & 463 & .247 & 630 \\
\hline & & Significance (2-tailed) & r. & .000 & .008 & .173 & .000 \\
\hline & & Df & 0 & 30 & 30 & 30 & 30 \\
\hline & CtiT & Correlation & .844 & 1.000 & .533 & 200 & .025 \\
\hline & & Significance (2-tailed) & .000 & . & .002 & .270 & .000 \\
\hline & & Df & 30 & 0 & 30 & 30 & 30 \\
\hline & SP & Correlation & .463 & .533 & 1.000 & .750 & .255 \\
\hline & & Significance (2-tailed) & .008 & .002 & ${ }^{\circ}$ & .000 & .159 \\
\hline & & Df & 30 & 30 & 0 & 30 & 30 \\
\hline & RIP & Correlation & .247 & .200 & .750 & 1.000 & .002 \\
\hline & & Significance (2-tailed) & 173 & .273 & .000 & . & .990 \\
\hline & & Df & 30 & 30 & 30 & 0 & 30 \\
\hline & TPET & Correlation & .630 & .625 & .255 & .002 & 1.000 \\
\hline & & Significance (2-tailed) & .000 & .000 & 159 & .990 & . \\
\hline & & Df & 30 & 30 & 30 & 30 & 0 \\
\hline \multirow[t]{12}{*}{ TPET } & & Correlation & 1.000 & .742 & 402 & .316 & \\
\hline & & Significance (2-tailed) & r & .000 & .025 & .083 & \\
\hline & & Df & 0 & 29 & 29 & 29 & \\
\hline & & Correlation & .742 & 1.000 & .496 & .254 & \\
\hline & & Significance (2-tailed) & .000 & . & .005 & .168 & \\
\hline & & Df & 29 & 0 & 29 & 29 & \\
\hline & & Correlation & .402 & .496 & 1.000 & .775 & \\
\hline & & Significance (2-tailed) & .025 & .005 & & .000 & \\
\hline & & Df & 29 & 29 & 0 & 29 & \\
\hline & & Correlation & .316 & .254 & .775 & 1.000 & \\
\hline & & Significance (2-tailed) & .083 & .168 & .000 & . & \\
\hline & & Df & 29 & 29 & 29 & 0 & \\
\hline
\end{tabular}

a. Cells contain zero-order (Pearson) correlations

Source: Author's calculation in SPSS. 
Generally, 5 out of 10 two-dimensional correlations are statistically significant and greater than or equal to 0.533 (positive correlations). However, the two-dimensional correlations between the variable "Skillset of graduates" on the one hand and the variables "Scientific Publications" and "Reputation of Scientific Organizations" on the other, are lower and not statistically significant. Generally speaking, the results of the twodimensional correlation indicate that if countries have a high score in one area of higher education system quality assessment, they usually have high scores in other areas of higher education system quality assessment (we have proved hypothesis 7).

The partial correlation coefficients were then calculated between the variables "Skillset of graduates", "Critical thinking in teaching", "Scientific Publications", and "Research institutions prominence", keeping the constant variable "Total public expenditure at tertiary level of education". Three of the six partial correlations are statistically significant and large. One of the most significant partial correlations is the partial correlation between the two measures of "strength" of the higher education system that are related to the quality of teaching (partial correlation between the variables "Skillset of graduates" and "Critical thinking in teaching", $r(34)=0.742, \mathrm{p}=0.000<0.006)$, while the second (largest or most significant) partial correlation relates to the evaluation of the quality of science and research at the university (partial correlation between the variables "Scientific publications" and "Research institutions prominence", $r(34)=0.775, p=0.000$ $<0.008$ ).

The results of partial correlation support the hypothesis that the quality of the higher education system in the assessment areas is highly dependent on the amount of public expenditure on higher education (see hypothesis 8 in the Methodological framework for research and hypotheses section). The empirical research presented above states that the state should give education a priority in the allocation of funds from the budget, which in itself has a positive effect on the quality of education and, consequently, the competitiveness of the economy (Mourato and Patrício, 2019).

\section{Conclusion}

The poor state of the higher education system is a significant constraint on the future growth and development of the economy. However, the perceived competitive disadvantages should be seen as a benchmark (priority) for undertaking future activities. In accordance with the key results of the analysis, presented in this paper, the measures and activities of the competent state authorities in the coming period should be directed towards: 1) improving the employability of students; 2) increasing funding for higher education and 3) developing science at university and 4) improving innovation capacity.

1) Improving employability of students. The primary objective of public policy of higher education in each country should be to improve the employability of students in the coming period. Employability refers to "a set of achievements - skills, knowledge and 
personal traits - that enable students to get a job and be successful in the profession they have chosen.

The following will address the following measures and activities of universities aimed at increasing employability of student: foundation of university business incubators, organizing student practices and implementing dual education systems in higher education. Improving business-university collaboration can help encourage the innovative potential of the firm and, at the same time, enable universities to improve opportunities of students' employment. Closer, universities can increase student employability and stimulate development of firms by establishing university business incubators (Voronov and Lavrinenko, 2014). University business incubators should function as a mechanism for transferring knowledge to firms. Interviews with representatives of firms located in university business incubators revealed that firms identified the following benefits arising from their relationships wuth incubator: increased strategic focus, improved R\&D activities, and a database for knowledge transfer. A special type of university business incubators are business villages that allow to small businesses to use premises and facilities (Adesola et al., 2019). Student internship programs may also extremely usefulness. Internship refers to work experience gained in the education process through a planned and supervised program (Piterou and Birch, 2016). In the study titled Internships in SMEs and career intentions, Andreas Walmsley, Rhordi Thomas and Stephanie Jameson indicate that most research on internships focuses on benefits for students and employers, but not for higher education institutions (Walmsley et al., 2012). Some of the benefits of an internship for students are: earlier job offers, higher starting wage, etc. Andreas Walmsley, Rhordi Thomas and Stephanie Jameson also indicate that students are improving their job search skills and developing networking opportunities. Employers (businesses) gain an advantage by developing competencies that allow them to evaluate how students' skills can be used in firm, as well as exposure to new ideas. We agree that the last point is more important for the development of innovation. Benefits for the university relate to: enhancing the reputation, improving the employability of students, the contribution of employers in creating curricula and networking universities with the local community (Pavlović, 2015; Melović, 2019; Slavić and Berber, 2019).

The next analyzed measure for improving the employability of students is the implementation of a dual education system in higher education institutions. The aim of such a system is overcoming the gap between the theoretical knowledge acquired during schooling, on the one hand, and the required practical skills in the labor market, on the other. Some studies at the application of the dual education system in higher education institutions have shown a higher rate of employability and easier orientation of students in the labor market, thanks to the ability and acquired skills to respond to tasks immediately after graduation, without the need for additional training (Mafenya, 2013; Lavrinovica and Lavrinenko, 2013).

2) Increasing of higher education funding. The research conducted in this paper shows that the higher education system will not be able to contribute to the development and 
growth of the economy as long as it faces serious funding problems. In order to increase funding for higher education, higher education institutions need to focus on other sources of funding, such as the new generation of EU funding for research, teaching and innovation funding in education (Pavlović, 2014; Ohotina and Lavrinenko, 2013).

3) Development of science at university and enhancement of innovation capacity. Considering the above results of the analysis, we can conclude, that there is extremely limited role of innovation in the economies of Romania, Northern Macedonia, Albania, Serbia and Bosnia and Herzegovina, which, combined with the unfavorable business climate, represents great challenge for these countries. The lag of these countries is especially evident when it comes to the formation of knowledge-based economy that enables the application of the results of fundamental research and the creation of products that meet consumer needs. Further progress and improvement of the position of Romania, Northern Macedonia, Albania, Serbia and Bosnia and Herzegovina on the global market includes successful implementation of the following measures: 1) formation of non-governmental funds that should be used to finance the most productive researchers and for other needs (procurement of materials, apparatus, samples and Similarly); 2) creation of high-paying permanent positions at colleges and institutes; 3 ) defining and implementing more stringent employment and promotion conditions (Piro, 2019; Krstić et al., 2018: Tošović-Stevanović et al., 2017).

\section{References}

1. ADESOLA, S., B. DEN OUTER, S. MUELLER, 2019. New entrepreneurial worlds: Can the use of role models in higher education inspire students? The case of Nigeria. Journal of Entrepreneurship in Emerging Economies. 11(4), 465-491.

2. BIAGI, F., C. LUCIFORA, 2008. Demographic and education effects on unemployment in Europe. Labour Economics. 15(5), 1076-1101.

3. CHENG, Y., 2015. Academic ranking of world universities (ARWU) by subjects and fields: Methodologies, challenges and future plans. Subject and Discipline Related Rankings-a More Inclusive Approach to University Performance (IREG 2015). Bruxelles: IREG Observatory on Academic Ranking and Excellence.

4. CAVALLI, L. S., M. V. BUTTOW, M. H. FERMINO, 2019. A importância da ciência e da publicação científica nas áreas agrárias: Um século de pesquisa agropecuária no sul do Brasil. Pesquisa Agropecuária Gaúcha. 5(3), 219-221.

5. DE LA FUENTE MORENO, A., J. F. J. SERRANO, 2005. The private and fiscal returns to schooling and the effect of public policies on private incentives to invest in education: a general framework and some results for the EU. Documentos de trabajo del Banco de España. (9), 1-82.

6. EC-DG ECFIN European Commission-Directorate General for Economic and Financial Affairs., Efficiency and effectiveness of public expenditure on tertiary education in the EU. In: EC-DG ECFIN European Commission-Directorate General for 
Economic and Financial Affairs [online]. Brussels: European Commission. [accessed: 2019-11-08]. Available from: http://ec.europa.eu/economy_finance.

7. EUROPEAN COMMISSION, 2001. Communication of the European Commission to the European Parliament and the Council on Strengthening Co-operation with Third Countries in the Field of Higher Education. Brussels: European Commission.

8. EUROPEAN COMMISSION, 2002. The concrete future objectives of education systems. Brussels: European Commission.

9. EUROPEAN COMMISSION REPRESENTATION IN UK, 2006. Delivering on the modernization agenda for universities; education, research and innovation. London: European Commission.

10. GEORGE, D., P. MALLERY, 2016. IBM SPSS statistics 23 step by step: A simple guide and reference. London: Routledge.

11. HIGHMAN, L., 2019. The distribution of EU students and staff at UK Universities: patterns and trends. Tertiary Education and Management. 25(4), 1-16.

12. HINTON, P. R., I. MCMURRAY, C. BROWNLOW, 2014. SPSS explained. London: Routledge.

13. KRSTIĆ, B., M. KRSTIĆ, 2015. Determinants of national economy competitiveness of Balkan countries - benchmarking study. In: Krstić, B. and Paszek, Z., Competitiveness of enterprises and national economies. Niš, Serbia: Faculty of Niš. 1-17.

14. KRSTIĆ, B., M. KRSTIĆ, 2017. Higher education as a factor of Serbian national economy competitiveness. In: Krstić, B. and Paszek, Z., Competitiveness of enterprises and national economies. Niš, Serbia: Faculty of Niš. 1-28.

15. KRSTIĆ, B., M. KRSTIĆ, I. ĐEKIĆ, 2018. A science as the determinant of competitiveness of countries - benchmarking study. In: Krstić B., Building competitiveness: micro and macro aspects. Niš, Serbia: Faculty of Niš. 1-25.

16. KRSTIĆ, M., 2018. Nauka i konkurentnost. In: Kostadinović A., Proces evropskih integracija i regionalna saradnja CONSTANTIN MAGNUS. Niš, Serbia: Fakultet za pravo, bezbednost i menadžment Konstantin Veliki. 321-339.

17. KRSTIĆ, M., B. KRSTIĆ, R. ANTONOVIĆ, 2019. The importance of science for improving competitiveness of national economy. Economics and Organization. 16(1), 13-30.

18. LAVRINOVICHA, I., O. LAVRINENKO, J. TEIVANS-TREINOVSKIS, 2015. Influence of education on unemployment rate and incomes of residents. Procedia-Social and Behavioral Sciences. 174, 3824-3831.

19. LAVRINOVICA, I., O. LAVRINENKO, 2013. Education as a factor of income differentiation of the population in Latvia within the period from 2000 to 2011. Procedia-Social and Behavioral Sciences. 106, 950-958.

20. LEECH, N. L., K. C. BARRETT, G. A. MORGAN, 2014. IBM SPSS for intermediate statistics: Use and interpretation. London: Routledge.

21. LISBON COUNCIL, 2007. European Growth and Jobs Monitor. Indicators for success in the Knowledge Economy. Frankfurt/Main: Allianz Dresdner Economic Research. 
22. LOVRINČEVIĆ, Ž., D. MIKULIĆ, E. RAJH, 2008. Usporedba metodologija mjerenja konkurentnosti nacionalnog gospodarstva i položaj Hrvatske. Ekonomski pregled. 59(11), 603-645.

23. MAFENYA, P. N., 2013. Investigation of the Collaborative Relationship between Industry and Academic Education in Open and Distance Learning: A South African Context. Mediterranean Journal of Social Sciences. 4(13), 43-50.

24. MELOVIĆ, B., 2019. Educational Management and Leadership in Montenegro. In: Ingpórsson, Á. H. et al., Educational Leadership in Policy. Cham, UK: Palgrave Macmillan, 245-264.

25. MBONIGABA, J., A. G. WILFRED, 2019. Productivity effects of human capital: an empirical investigation of health and higher education in South Africa. Zbornik radova Ekonomskog fakulteta u Rijeci: časopis za ekonomsku teoriju i praksu. 37(1), 277-301.

26. MOURATO, J., M. T. PATRÍCIO, 2019. Evaluation and control process in higher education institutions: a comparative analysis. Quality Assurance in Education. 27(3), 269-284.

27. OHOTINA, A., O. LAVRINENKO, 2013. Influence of the higher education on the investment climate. Procedia-Social and Behavioral Sciences. 106, 1470-1475.

28. PAVLOVIĆ, N., 2014. Influence of Head Teacher's Leadership Style on Tutor Satisfaction. Stanisław Juszczyk. 35(2), 266-278.

29. PAVLOVIĆ, N., 2015. Authentic Leadership in Educational Institutions. International Journal for Quality Research. 9(2), 309-322.

30. PAVLOVIĆ, N., 2017. The Role of Social Participants in the Evaluation of Teachers at Universities in Serbia. Transylvanian Review. 26(1), 74-89.

31. PIRO, F. N., 2019. The R\&D composition of European countries: concentrated versus dispersed profiles. Scientometrics. 119(2), 1095-1119.

32. PITEROU, A., C. BIRCH, 2016. The role of higher education institutions in supporting innovation in SMEs: University-based incubators and student internships as knowledge transfer tools. InImpact: The Journal of Innovation Impact. 7(1), 72-79.

33. SAVIĆ, B., I. MILOJEVIĆ, V. PETROVIC, 2019. Cost optimization in agribusiness based on life cycle costing. Economics of Agriculture. 66(3), 823-834.

34. SCHWAB, K., 2019. The global competitiveness report 2019. Geneva: World Economic Forum.

35. SLAVIĆ, A., N. BERBER, 2019. The role of training practice in improving organizational performance in selected countries of the Danube region. Engineering Economics. 30(1), 81-93.

36. TOPIĆ, M., 2014. Forging the reform: bologna reform between the national and the European, the traditional and the 'modern'. Facta Universitatis-Law and Politics. 12(1), 21-41.

37. TOŠOVIĆ-STEVANOVIĆ, A., A. JURČIĆ, M. RABRENOVIĆ, 2017. Cultural aspects of management and their impact on competitiveness of countries. Megatrend revija. 14(3), 149-163. 
38. VORONOV, V., LAVRINENKO O., 2014. Knowledge management and the incresase of SME competitiveness: a case study. Baltic Region. 3(21), 22-32.

39. WALMSLEY, A., R. THOMAS, S. JAMESON, 2012. Internships in SMEs and career intentions. Journal of Education and Work. 25(2), 185-204.

\section{Acknowledgement}

Funding for the publication of this article provided by the Ministry of Education, Science and Technological Development of the Republic of Serbia.

\section{Contact address of the authors:}

Miloš Krstić, Ph.D., Faculty of Science and Mathematics, University of Niš, Višegradska 33, Niš, Serbia, e-mail: krsticmilo3@email.com

Nebojša Pavlović, Ph.D., Faculty of Hotel and Turism, University of Kragujevac, Vojvodjanska bb 36210, Vrnjacka Banja, Serbia, e-mail: racapn@email.com 


\section{Attachment}

Figure 1: Selected results of multiple regression with selected set of predictor variables

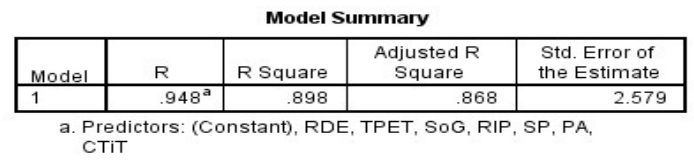

\begin{tabular}{|c|c|c|c|c|c|c|}
\hline \multicolumn{7}{|c|}{ ANOVA $^{a}$} \\
\hline & & $\begin{array}{l}\text { Sum of } \\
\text { Squares }\end{array}$ & df & Mean Square & $\mathrm{F}$ & Sig. \\
\hline \multirow[t]{3}{*}{1} & Regression & 1402.870 & $\overline{7}$ & 200.410 & 30.137 & $.000^{\mathrm{b}}$ \\
\hline & Residual & 159.599 & 24 & 6.650 & & \\
\hline & Total & 1562.469 & 31 & & & \\
\hline
\end{tabular}

a. Dependent Variable: $\mathrm{GCl}$

b. Predictors: (Constant), RDE, TPET, SoG, RIP, SP, PA, CTIT

\begin{tabular}{|c|c|c|c|c|c|c|c|c|c|c|c|}
\hline \multicolumn{12}{|c|}{ Coefficients $^{a}$} \\
\hline \multirow{2}{*}{\multicolumn{2}{|c|}{ Model }} & \multicolumn{2}{|c|}{ Unstandardized Coefficients } & \multirow{2}{*}{$\begin{array}{c}\begin{array}{c}\text { Standardized } \\
\text { Coefficients }\end{array} \\
\text { Beta } \\
\end{array}$} & \multirow[b]{2}{*}{$t$} & \multirow[b]{2}{*}{ Sig. } & \multicolumn{2}{|c|}{ 95.0\% Confidence Interval for B } & \multicolumn{3}{|c|}{ Correlations } \\
\hline & & $B$ & Std. Error & & & & Lower Bound & Upper Bound & Zero-order & Partial & Part \\
\hline \multirow[t]{8}{*}{1} & (Constant) & 43.978 & 4.800 & & 9.161 & .000 & 34.071 & 53.886 & & & \\
\hline & Sog & 2.543 & 1.450 & .232 & 1.754 & .092 & -.449 & 5.536 & .808 & .337 & .114 \\
\hline & СTiT & 2.371 & 1.258 & .292 & 1.885 & .072 & -.225 & 4.967 & .844 & .359 & 123 \\
\hline & SP & .009 & .003 & .393 & 3.099 & .005 & .003 & .015 & .774 & .535 & 202 \\
\hline & PA & .010 & .011 & .123 & .846 & .406 & -.014 & .033 & .847 & .170 & .055 \\
\hline & RIP & 1.789 & 2.903 & .075 & .616 & .543 & -4.203 & 7.782 & .501 & .125 & .040 \\
\hline & TPET & 1.127 & 1.422 & .075 & .792 & .436 & -1.808 & 4.061 & .578 & .160 & .052 \\
\hline & RDE & .000 & .000 & -.061 & -.590 & .561 & -.001 & .000 & .424 & -.120 & tiva.039 \\
\hline
\end{tabular}

Source: Calculation of authors - SPSS.

Figure 2: Selected results of multiple regression analysis for two unordered sets of predictor variables

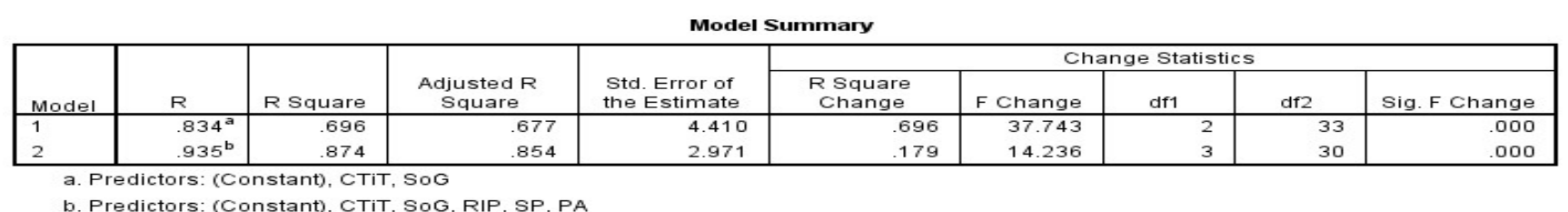

b. Predictors: (Constant), CTIT, SoG, RIP, SP, PA

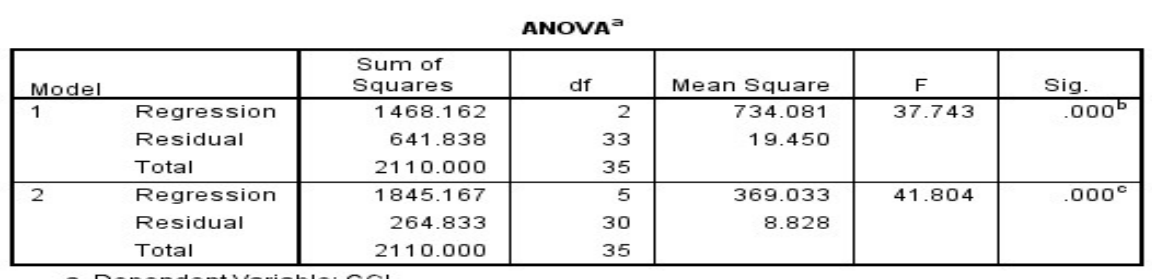

a. Dependent Variable: $\mathrm{GCl}$

b. Predictors: (Constant), CTIT, SoG

c. Predictors: (Constant), CTIT, SoG, RIP, SP, PA

\begin{tabular}{|c|c|c|c|c|c|c|c|c|c|c|c|}
\hline \multicolumn{12}{|c|}{ Coefficients $^{a}$} \\
\hline & & \multicolumn{2}{|c|}{ Unstandardized coefficients } & \multirow{2}{*}{$\begin{array}{c}\text { Standardized } \\
\text { coefficients }\end{array}$} & & \multirow[b]{2}{*}{ sig. } & \multicolumn{2}{|c|}{$95.0 \%$ Confidence Interval for $B$} & \multicolumn{3}{|c|}{ correlations } \\
\hline Model & & $\mathrm{B}$ & Std. Error & & & & Lower Bound & Upper Bound & Zero-order & Partial & Part \\
\hline 1 & $\begin{array}{l}\text { (Constant) } \\
\text { SaG } \\
\text { CTiT }\end{array}$ & $\begin{array}{r}30.566 \\
6.804 \\
2.409\end{array}$ & $\begin{array}{l}5.166 \\
2.002 \\
1.558\end{array}$ & $\begin{array}{l}.595 \\
.271\end{array}$ & $\begin{array}{l}5.916 \\
3.399 \\
1.546\end{array}$ & $\begin{array}{l}.000 \\
.002 \\
.132\end{array}$ & $\begin{array}{r}20.055 \\
2.732 \\
-.760\end{array}$ & $\begin{array}{r}41.077 \\
10.877 \\
5.578\end{array}$ & $\begin{array}{l}.821 \\
.768\end{array}$ & $\begin{array}{l}.509 \\
.260\end{array}$ & $\begin{array}{l}.326 \\
.148\end{array}$ \\
\hline 2 & (Constant) & 40.593 & 4.763 & & 8.523 & .000 & 30.866 & 50.321 & & & \\
\hline & sog & 5.124 & 1.422 & .448 & 3.605 & .001 & 2.221 & 8.027 & .821 & .550 & 233 \\
\hline & СTiT & .279 & 1.210 & . .031 & .231 & .819 & -2.193 & 2.751 & .768 & .042 & 015 \\
\hline & SP & .011 & .003 & .460 & 3.883 & .001 & .005 & .017 & .763 & .578 & 251 \\
\hline & PA & .018 & .011 & 199 & 1.555 & .130 & -.006 & .041 & .834 & .273 & 101 \\
\hline & RIP & -1.867 & 2.866 & -.069 & -.651 & 520 & -7.720 & 3.987 & 491 & -.118 & -.042 \\
\hline
\end{tabular}

Source: Calculation of authors - SPSS. 
Figure 3: Selected results of multiple regression analysis for two unordered sets of predictor variables

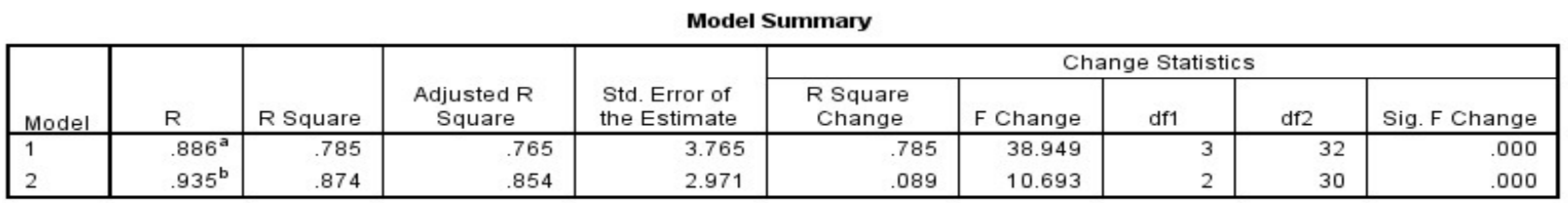

a. Predictors: (Constant), RIP, PA, SP

b. Predictors: (Constant), RIP, PA, SP, SoG, CTiT

\begin{tabular}{|ll|r|r|r|r|r|}
\hline \multicolumn{1}{|c|}{ ANOVA $^{\text {a }}$} \\
Model & & $\begin{array}{c}\text { Sum of } \\
\text { Squares }\end{array}$ & df & Mean Square & F & Sig. \\
\hline 1 & Regression & 1656.378 & 3 & 552.126 & 38.949 & $.000^{\circ}$ \\
& Residual & 453.622 & 32 & 14.176 & & \\
& Total & 2110.000 & 35 & & & \\
\hline 2 & Regression & 1845.167 & 5 & 369.033 & 41.804 & $.000^{\circ}$ \\
& Residual & 264.833 & 30 & 8.828 & & \\
& Total & 2110.000 & 35 & & & \\
\end{tabular}

a. Dependent Variable: GCI

b. Predictors: (Constant), RIP, PA, SP

c. Predictors: (Constant), RIP, PA, SP, SoG, CTIT

\begin{tabular}{|c|c|c|c|c|c|c|c|c|c|c|c|}
\hline \multicolumn{12}{|c|}{ Coefficients $^{a}$} \\
\hline & & \multicolumn{2}{|c|}{ Unstandardized Coefficients } & $\begin{array}{c}\text { Standardized } \\
\text { Coefficients }\end{array}$ & \multirow[b]{2}{*}{$t$} & \multirow[b]{2}{*}{ Sig. } & \multicolumn{2}{|c|}{$95.0 \%$ Confidence Interval for B } & \multicolumn{3}{|c|}{ Correlations } \\
\hline \multicolumn{2}{|c|}{ Model } & B & Std. Error & Beta & & & Lower Bound & Upper Bound & Zero-order & Partial & Part \\
\hline \multirow[t]{4}{*}{1} & (Constant) & 62.161 & 1.156 & & 53.770 & .000 & 59.806 & 64.516 & & & \\
\hline & SP & .012 & .004 & .502 & 3.420 & .002 & .005 & .019 & .763 & .517 & .280 \\
\hline & PA & .051 & .010 & .578 & 5.267 & .000 & .031 & .071 & .834 & .681 & .432 \\
\hline & RIP & -4.363 & 3.377 & -.161 & -1.292 & .206 & -11.242 & 2.515 & .491 & -.223 & -.106 \\
\hline \multirow[t]{6}{*}{2} & (Constant) & 40.593 & 4.763 & & 8.523 & .000 & 30.866 & 50.321 & & & \\
\hline & SP & .011 & .003 & .460 & 3.883 & .001 & .005 & .017 & .763 & .578 & .251 \\
\hline & PA & .018 & .011 & .199 & 1.555 & .130 & -.006 & .041 & .834 & .273 & .101 \\
\hline & RIP & -1.867 & 2.866 & -.069 & -.651 & .520 & -7.720 & 3.987 & .491 & -.118 & -.042 \\
\hline & SoG & 5.124 & 1.422 & .448 & 3.605 & .001 & 2.221 & 8.027 & .821 & .550 & .233 \\
\hline & СТіT & .279 & 1.210 & .031 & .231 & .819 & -2.193 & 2.751 & .768 & .042 & .015 \\
\hline
\end{tabular}

a. Dependent Variable: $\mathrm{GCl}$

Source: Calculation of authors - SPSS.

Figure 4: Results of multiple regression with two ordered sets of predictor variables

\begin{tabular}{|c|c|c|c|c|c|c|c|c|c|}
\hline \multirow[b]{3}{*}{ Model } & \multirow[b]{3}{*}{$\mathrm{R}$} & \multirow[b]{3}{*}{ R Square } & \multicolumn{6}{|c|}{ Model Summary } & \\
\hline & & & \multirow[b]{2}{*}{$\begin{array}{l}\text { Adjusted R } \\
\text { Square }\end{array}$} & \multirow[b]{2}{*}{$\begin{array}{l}\text { Std. Error of } \\
\text { the Estimate }\end{array}$} & \multicolumn{5}{|c|}{ Change Statistics } \\
\hline & & & & & $\begin{array}{c}\text { R Square } \\
\text { Change }\end{array}$ & F Change & df1 & df2 & Sig. F Change \\
\hline 1 & $.927^{\mathrm{a}}$ & .859 & .824 & 2.26783 & .859 & 24.441 & 2 & 8 & .000 \\
\hline 2 & $1.000^{\mathrm{b}}$ & 1.000 & .999 & .14840 & .141 & 266.746 & 7 & 1 & .047 \\
\hline
\end{tabular}

a. Predictors: (Constant), GDPpc, Export

b. Predictors: (Constant), GDPpc, Export, CTIT, SP, TPET, RIP, SoG, RDE, PA

\begin{tabular}{|c|c|c|c|c|c|c|}
\hline \multicolumn{7}{|c|}{ ANOVA $^{a}$} \\
\hline & & $\begin{array}{l}\text { Sum of } \\
\text { Squares }\end{array}$ & df & Mean Square & $\mathrm{F}$ & Sig. \\
\hline \multirow[t]{3}{*}{$\frac{1}{1}$} & Regression & 251.401 & 2 & 125.700 & 24.441 & $.000^{\mathrm{b}}$ \\
\hline & Residual & 41.144 & 8 & 5.143 & & \\
\hline & Total & 292.545 & 10 & & & \\
\hline \multirow[t]{3}{*}{2} & Regression & 292.523 & 9 & 32.503 & 1475.826 & $.020^{\circ}$ \\
\hline & Residual & .022 & 1 & .022 & & \\
\hline & Total & 292.545 & 10 & & & \\
\hline
\end{tabular}

a. Dependent Variable: $\mathrm{GCl}$

b. Predictors: (Constant), GDPpc, Export

c. Predictors: (Constant), GDPpc, Export, CTIT, SP, TPET, RIP, SoG, RDE, PA

Source: Calculation of authors - SPSS. 